\title{
The Anti-Nutritional and Proximate Composition of Rain Tree (Samanea saman) Pod Samples
}

\author{
Uzoukwu, A. E ${ }^{1}$ \\ Ubbaonu, C. $\mathrm{N}^{2}$ (D) \\ Nwosu, J. N. ${ }^{3}$ \\ Ogueke, C. C. ${ }^{4}$ \\ Chukwu, M. N. ${ }^{5}$
}

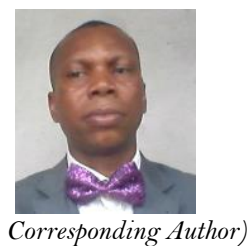

( Corresponding Author)

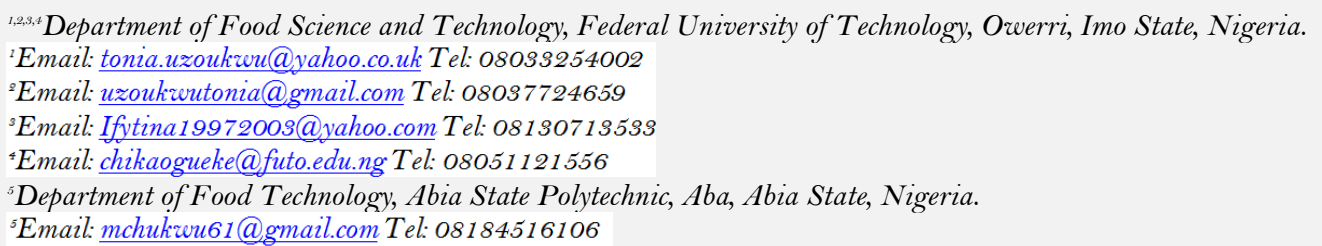

\section{Abstract}

The anti-nutritional and proximate composition of pods of Samanea saman were determined. About $600 \mathrm{~g}$ of wholesome, cleaned and dried pods were divided into two portions: one portion was ground as whole pod meal while the other portion was deseeded and ground as seedless meal. The removed seeds were ground separately as a sample to obtain three samples namely: whole pod, pulp and seed samples. Triplicate data obtained were subjected to One-Way ANOVA using SPSS software of version 21. Mean values and Fisher's least significant difference (LSD) were determined for the separation of the means at $(\mathrm{p} \leq 0.05)$. The whole pod had $1.49 \mathrm{mg} / 100 \mathrm{~g}$ oxalate, $1.97 \mathrm{mg} / 100 \mathrm{~g}$ hydrogen cyanide, $0.71 \mathrm{mg} / 100 \mathrm{~g}$ tannins, $27.07 \mathrm{mg} / 100 \mathrm{~g}$ saponins, $0.51 \mathrm{mg} / 100 \mathrm{~g}$ flavonoids and $1.71 \mathrm{mg} / 100 \mathrm{~g}$ alkaloids, which were significantly $(\mathrm{p} \leq 0.05)$ different from that of pulp $(1.89 \mathrm{mg} / 100 \mathrm{~g}$ oxalate, $1.51 \mathrm{mg} / 100 \mathrm{~g}$ hydrogen cyanide, $0.86 \mathrm{mg} / 100 \mathrm{~g}$ tannins, $28.46 \mathrm{mg} / 100 \mathrm{~g}$ saponins, $1.00 \mathrm{mg} / 100 \mathrm{~g}$ flavonoids and $1.41 \mathrm{mg} / 100 \mathrm{~g}$ alkaloids) and seed samples (1.39mg/100g oxalate, $1.61 \mathrm{mg} 100 \mathrm{~g}$ hydrogen cyanide, $0.56 \mathrm{mg} / 100 \mathrm{~g}$ tannins, $26.51 \mathrm{mg} / 100 \mathrm{~g}$ saponins, $0.49 \mathrm{mg} / 100 \mathrm{~g}$ flavonoids and $1.86 \mathrm{mg} / 100 \mathrm{~g}$ alkaloids). The moisture contents were pulp $(19.30 \%)$, whole pod $(15.50 \%)$ and seed $(9.20 \%)$. Ash content were whole pod $(4.70 \%)$, pulp $(2.90 \%)$ and seed (2.60\%); Ether extract of whole pod, pulp and seed were $3.31 \%, 2.52 \%$ and $2.66 \%$ respectively. The crude proteins were whole pod (13.21\%), pulp (10.98\%) and seed (21.55\%); crude fibre of the plant were whole pod $(15.95 \%)$, pulp $(6.77 \%)$ and seed $(8.47 \%)$. The whole pod had $47.33 \%$ carbohydrate which was significantly $(\mathrm{p} \leq 0.05)$ lower than the carbohydrate of pulp $(57.53 \%)$ and seed $(55.52 \%)$. The utilization of the pods of $S$. samana is a significant source of bioactive that if harnessed in the formulation of nutraceutical beverage could offer a whole lot of health benefit to the users.

Keywords: Saponins, Tannin, Alkaloid, Oxalate, Flavonoid, Moisture, Proteins, Ash, Fibre, Carbohydrate.

Citation | Uzoukwu, A. E; Ubbaonu, C. N; Nwosu, J. N.; Ogueke, C. C.; Chukwu, M. N. (2020). The Anti-Nutritional and Proximate Composition of Rain Tree (Samanea saman) Pod Samples. Agriculture and Food Sciences Research, 7(1): 28-37.

History:

Received: 2 January 2020

Revised: 6 February 2020

Accepted: 12 March 2090

Published: 8 April 2000

Licensed: This work is licensed under a Creative Commons

Attribution 3.0 License (oc)

Publisher: Asian Online Journal Publishing Group
Acknowledgement: All authors contributed to the conception and design of Acknowledge study.

Funding: This study received no specific financial support.

Competing Interests: The authors declare that they have no conflict of interests.

Transparency: The authors confirm that the manuscript is an honest, accurate, and transparent account of the study was reported; that no vital features of the study have been omitted; and that any discrepancies from the study as planned have been explained.

Ethical: This study follows all ethical practices during writing.

\section{Contents}

1. Introduction

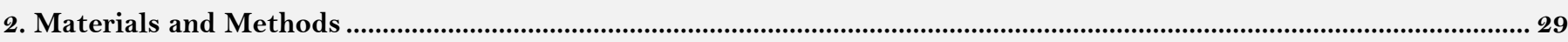

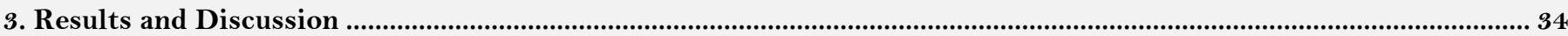

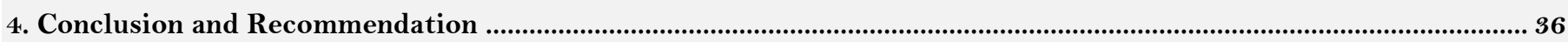

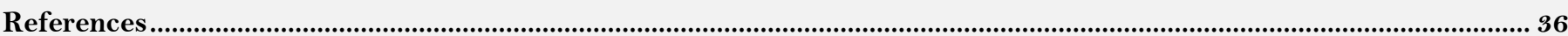




\section{Contribution of this paper to the literature}

This study has provided information for the utilization of the rain tree (Samanea saman) pod in food production. This study has also opened another area of research such as pod utilization in food formulation and animal feed development.

\section{Introduction}

The rain tree (Samanea saman Merr.) belongs to the family of leguminosae (pulse family) [1]. It is commonly called "Saman", "Rain tree", "monkey pod" and "Cow tarmarind" in English, while it is called "Acacia preta" and "Cenizaro" in Spain. The French call it "abre de Pluie" and the Philipines call it "Mimosa". The name "Rain tree" was believed to have originated from the leaflets which are light-sensitive and close together on cloudy days or nights, allowing rain to fall through the leaves to the ground below [2]. It is native to Northern South America and has naturalized throughout the tropics. The plant is easily recognized by its characteristic umbrella-shaped canopy giving it a domed shape [3].

Samanea saman is a multipurpose tree and is the botanical name for rain tree, 5 'O clock tree or monkey pod. $S$. saman is native to Northern South America but currently naturalized and distributed throughout the tropics. $S$. saman often planted in parks and pastures, vacant lots, churches and school grounds, along roadsides and planned landscape. $S$. saman is moderately fast growing with a growth rate of $0.75-1.5 \mathrm{~m} /$ year. Outdoors planting is done when the seedlings are 3-5 months old and $20-30 \mathrm{~cm}$ tall. It grows best in lowlands from sea level to $300 \mathrm{~m}$ high and rainfall of 600-3,000 $\mathrm{mm}[4,5]$. The pods of Samanea saman (Jack) Merr tree is straight, some-what fleshy, indehiscent, 15 to 20 centimeters long and 2 centimeter wide. When the pod ripens, the pulp is sweet and sugary with a flavor like licorice that is much relished by children. In South America, the sweet pulp is cooked like a tamarind. The seeds are oblong and reddish in color. Goats can eat the leaves and pods when feeds are scarce and the fruiting season of this tree coincides with the scarcity of good quality forages [6].

The nutritional composition of Samanea saman pods and seeds as having crude protein values of $16.6 \%$ and $31.6 \%$, crude fibre values of $12.0 \%$ and $14.0 \%$, ether extract values of $1.4 \%$ and $4.3 \%$, ash values of $3.5 \%$ and $4.3 \%$, carbohydrate values of $18.5 \%$ and $20.3 \%$ respectively. The ripe fallen pod is commonly eaten by children and animals [7] while the sweet, sticky pulp is used in the production of fruit drink similar to tamarindo in Latin America $[2,8]$.

The pods are edible and eagerly eaten by human and livestock (cattle, goat) both domesticated and wildlife. The seed of $S$. saman is already a good source of protein and energy. It contains $13.57 \%$ protein, $89.25 \%$ dry matter, $2.98 \%$ ether extract (EE), $2.19 \%$ crude fibre, $0.23 \%$ ash, and $6.44 \%$ nitrogen extract. Apart from its nutrient content which is almost comparable to corn, the pod is easily available making it a cheap source of feed for chickens Cruz [9]. Staples and Elevitch [2] reported that rain tree pods are nutritious with $12-18 \%$ protein, $40 \%$ digestibility and because of the sweet pulp are eagerly eaten by cattle, hogs, horses and goats. According to Barcelo and Barcelo [6] fresh Samanea saman (Jack) Merr pods had dry matter content of $84.82 \%$, crude protein of $9.45 \%$, crude fiber of $8.34 \%$, crude fat of $8.82 \%$ and ash of $5.12 \%$. The Samanea saman (Jack) Merrpod is rich in carbo-hydrates as reflected in its nitrogen-free extract of $53.09 \%$. Samanea saman (Jack) Merr pods are relished by livestock due to its sweet taste. The seeds are also surrounded by sticky, gummy substance.

The whole pods are used as feed and nutrient supplements for mammals such as squirrels, cows, cattle and goats. Okonkwo [10] reported that its seed has been used in the production of a local condiment called Anyu, However, the few works done on this pod were directed towards determining their anti-microbial and phytochemical potentials, and the use of their seeds in the production of "Anyu" a local condiment [10-12]. Available literature shows there is little or no research work on the use of these pods in their utilization in other commercial food products such as bread, yet these pods are wasting in the gardens and road-sides where the trees are planted for ornamental purposes. Even in the campus of Federal University of Technology, Owerri (FUTO), the trees fruit heavily and animals (cows or others) at their will pick up the heavily littering pods within the fruiting season [6].

Anti-nutrients are natural or synthetic compounds that interfere with the absorption of nutrients [13]. Antinutritional factors are present in different food substances in varying amounts, depending on the kind of food, mode of its propagation, chemicals used in growing the crop as well as those chemicals used in storage and preservation of the food substances $[14,15]$. Some oil seeds and legumes used in the production of foods contain toxic substances and anti-nutritional factors; for example, tannin in castor oil bean, trypsin inhibitors in soybean, oxalates in locust beans, phytic acid in African oil bean, phytate in melon seeds [16, 17]. Despite the protein quality in leguminous seeds, it does not however reach the same level as in animal products. This is due to unbalanced amino acids, presence of anti-nutritional factors and low digestibility of protein. Processing methods, such as soaking, cooking or fermentation can improve the quality of legume protein [18]. During fermentation, micro flora may produce proteolytic enzymes which may be responsible for the increase in protein digestibility. Also, the elimination of phytic acid contributes to the improvement in protein digestibility of fermented products [19].

The main objective of this research is to investigate the anti-nutritional and proximate composition of rain tree pod. The specific objectives are to analyze the anti-nutrients and proximate composition of Samanea saman whole pods, pulp and seeds. The notable sweetness of the rain tree pulp when applied in food is hoped to provide an alternative source of sugar for food production, with a resultant reduction in the cost of production and consequently the price of food in the market. Besides, it's distinct but attractive flavour may introduce a variety in food products. A good result from this study will certainly introduce the underutilized pods to the food industry and add economic value to it.

\section{Materials and Methods \\ 2.1. Collection of Materials}

Some ripe, fallen wholesome rain tree (Samanea saman) pods were picked from the tree sites around the School of Agriculture and Agricultural Technology (SAAT) of the Federal University of Technology, Owerri (FUTO), 
Imo State, Nigeria. Some of the chemicals used for the analyses were obtained from the Department of Food Science and Technology laboratory, and School of Agriculture and Agricultural Technology laboratory in FUTO. Others were purchased from the Finlab Store Owerri, Imo State, Nigeria. Some of the analyses were conducted in the laboratories of the Department of Food Science and Technology and School of Agriculture and Agricultural Technology, FUTO, while others were carried out in the Department of Zoology laboratory of University of Jos and International Institute for Tropical Agriculture (IITA), Ibadan, Oyo State, Nigeria.

\subsection{Methods}

2.2.1. Preparation of Samples

The pods were picked at various times from the tree site, sorted, washed and sun dried for about five days. Six hundred grams (600g) of wholesome, cleaned and dried pods were divided into two portions; one portion was ground as whole pod meal (sample 1) shown in Figure 1 and Figure 2, while the other portion was deseeded and ground as seedless meal (sample 2) as shown in Figure 2. Then the removed seeds Figure 3 were collected and ground separately as a sample (Sample 3) to obtain three samples for the desired raw material analyses, namely whole pod, pulp and seed samples [20].

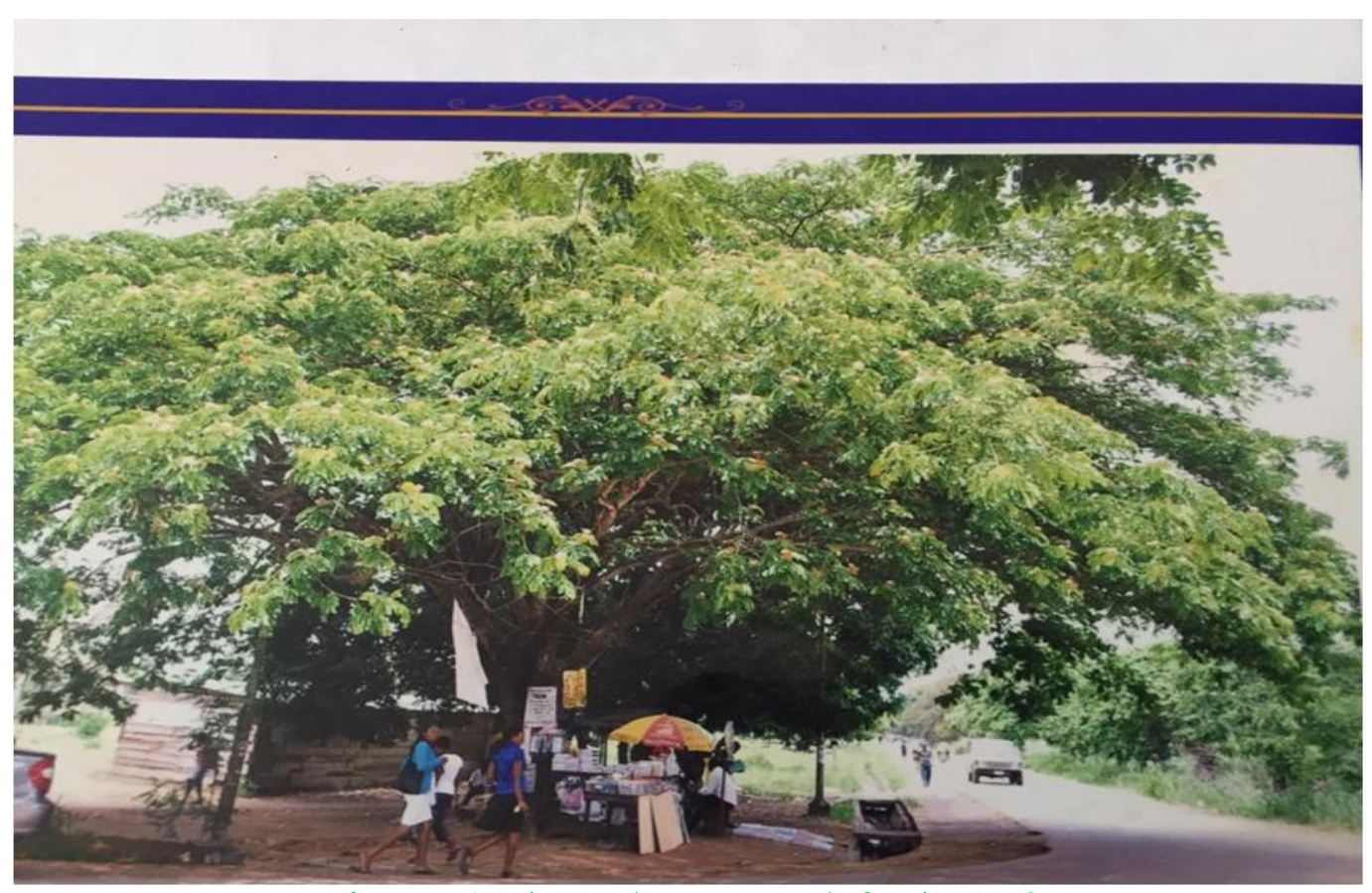

Figure-1. A Rain Tree (Samanea saman) Plant in FUTO.

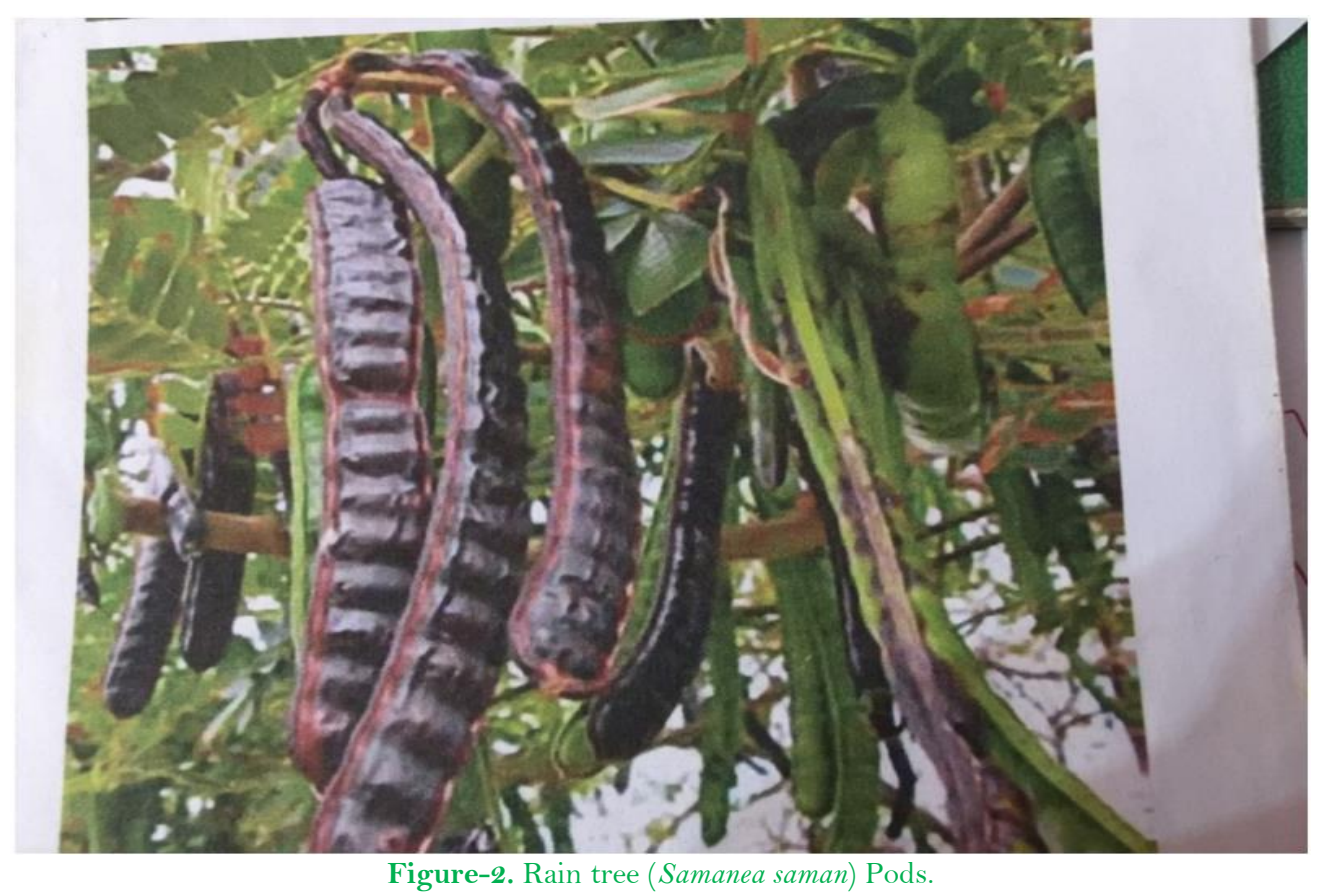




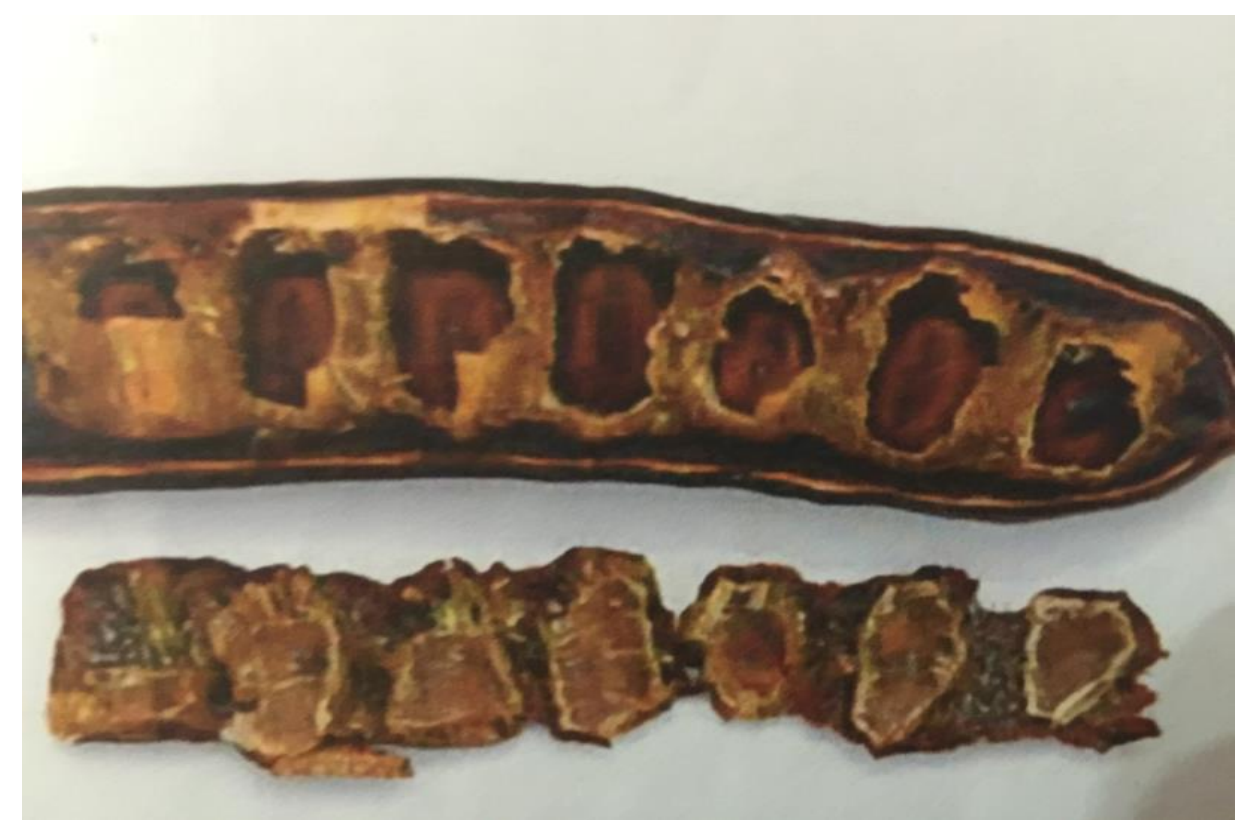

Figure-3. Rain tree (Samanea saman) Seeds.

2.2.2. Determination of Anti-Nutrients in the Pods of Rain Tree

2.2.2.1. Saponin Content

The method described by Okwu [21] was used for the analyses of the anti-nutrients. Twenty-five grams $(25 \mathrm{~g})$ of the sample was placed in a two hundred and fifty milliliters $(250 \mathrm{ml})$ flask. One hundred milliliters (100ml) of $20 \%(\mathrm{~V} / \mathrm{V})$ aqueous solution of ethanol was poured into the flask; then the flask with the content was placed in a hot water bath at $55^{\circ} \mathrm{C}$ for 4 hours with occasional stirring. The mixture was filtered and the residue re-extracted with a fresh $100 \mathrm{ml}$ of $20 \%(\mathrm{~V} / \mathrm{V})$ ethanol solution as before. Both extracts were combined and the volume reduced to about $50 \mathrm{ml}$ in a water bath set at $90^{\circ} \mathrm{C}$. The mixture was allowed to cool, extracted with $20 \mathrm{ml}$ of diethyl ether in a $250 \mathrm{ml}$ separating funnel. The ether layer was discarded and $50 \mathrm{ml}$ of $\mathrm{n}$-butanol was poured into the lower layer. The mixture was shaken and the two layers allowed separating. The organic layer was washed twice with $10 \mathrm{ml}$ of $5 \%(\mathrm{~V} / \mathrm{V})$ sodium chloride solution in a separating funnel. This was poured into a pre-weighed beaker and evaporated to dryness on a boiling water bath. The beaker was cooled and weighed again [22]. The percentage saponin content was determined using Equation 1.

Where

$$
\% \text { Saponin }=\frac{W_{3}-W_{2}}{W_{1}} \times \frac{100}{1}
$$

$\mathrm{W}_{3}=$ Weight of beaker and residue after evaporation to dryness.

$\mathrm{W}_{2}=$ Weight of beaker alone.

$\mathrm{W}_{1}=$ Weight of sample.

\subsubsection{Flavonoid Content}

Two grams (2g) of the ground sample was placed in a $250 \mathrm{ml}$ Erlenmeyer flask and $100 \mathrm{ml}$ of $80 \%(\mathrm{~V} / \mathrm{V})$ methanol solution was added. The mixture was stirred with a magnetic stirrer for 3 hours and filtered with Whatman filter paper (No. 42). The residue was extracted with a fresh $100 \mathrm{ml}$ of $80 \%(\mathrm{~V} / \mathrm{V})$ methanol as before and the mixture filtered again. Both extracts were combined into a pre-weighed beaker and evaporated to dryness on a boiling water bath. This was cooled and weighed again [23]. The percentage flavonoid content was determined using Equation 2.

Where:

$$
\% \text { Flavonoid }=\frac{W_{3}-W_{2}}{W_{1}} \times \frac{100}{1}
$$

$\mathrm{W}_{3}=$ Weight of beaker and flavonoid.

$\mathrm{W}_{2}=$ Weight of beaker.

$\mathrm{W}_{1}=$ Weight of sample.

\subsubsection{Determination of Alkaloid Content}

Two grams $(2 \mathrm{~g})$ of the ground sample was placed in a $250 \mathrm{ml}$ flask and $100 \mathrm{ml}$ of $20 \%(\mathrm{~V} / \mathrm{V})$ acetic acid in ethanol was added to the flask. The flask was covered and allowed to stand for 4 hours while stirring with a magnetic stirrer. The mixture was filtered and the residue re-extracted with a fresh $100 \mathrm{ml}$ of $20 \%(\mathrm{~V} / \mathrm{V})$ ethanolic acetic acid solution. Both extracts were combined in a beaker and concentrated on a water bath to about one quarter of the original volume. The concentrate was cooled and concentrated ammonium hydroxide added in drops until complete precipitation of the alkaloids had occurred. The resulting mixture was allowed to stand overnight. Thereafter, it was filtered using a pre-weighed filter paper. The filter paper with the content was dried in an oven set at $70^{\circ} \mathrm{C}$ for 6 hours and cooled to ambient temperature in a desiccator. The weight of the filter paper and its contents were taken [24, 25]. The percentage alkaloid content was determined using Equation 3.

Where

$$
\% \text { Alkaloids }=\frac{W_{3}-W_{2}}{W_{1}} \times \frac{100}{1}
$$

$\mathrm{W}_{3}=$ Weight of filter and alkaloids after drying.

$\mathrm{W}_{2}=$ Weight of filter paper alone.

$\mathrm{W}_{1}=$ Weight of sample. 


\subsubsection{Determination of Tannin Content}

About 0.5grams portion of the ground sample was placed in a $100 \mathrm{ml}$ flask and fifty milliliters (50ml) of distilled water was added and the mixture was stirred for about one hour with a magnetic stirrer. The sample was filtered with a moist filter paper into a fifty milliliters $(50 \mathrm{ml})$ volumetric flask and made up to the mark with distilled water. Five milliliters $(5 \mathrm{ml})$ of the filtrate was pipette into a tube and mixed with three milliliters $(3 \mathrm{ml})$ of $0.1 \mathrm{ml}$ of ferricchloride in $0.1 \mathrm{~N}$ hydrochloric acid and $0.008 \mathrm{M}$ potassium ferrocyanide solution. The absorbance was measured in a spectrophotometer set at 120nm wavelength within ten (10) minutes of mixing. A blank sample was prepared and the colour was developed and read at the same wavelength. A standard was prepared using tannic acid to get 100ppm and measured [26]. The tannin content was calculated using the Equation 4:

$$
M g / m l \text { Tannin }=\text { Absorbance of sample } X \frac{\text { concentration of standard }}{1}
$$

\subsubsection{Determination of Cyanogenic Glycoside Content}

One gram $(1 \mathrm{~g})$ of the ground sample was placed in a round bottom flask and $200 \mathrm{ml}$ of de-ionized distilled water was added and the flask allowed standing for 2 hours. A distillation unit was set up and about $150 \mathrm{mls}$ of the reaction mixture (sample and de-ionized distilled water) was distilled into a $250 \mathrm{ml}$ receiver flask containing $20 \mathrm{ml}$ of $2.5 \%(\mathrm{~W} / \mathrm{V})$ sodium hydroxide solution. One hundred milliliters $(100 \mathrm{ml})$ of the mixture was measured into a $250 \mathrm{ml}$ flask and $8 \mathrm{ml}$ of $6 \mathrm{M}$ ammonium hydroxide solution was added followed by $2 \mathrm{ml}$ of $5 \%$ potassium iodide solution. The content of the flask was mixed and titrated with $0.02 \mathrm{~N}$ silver nitrate solution till there was no further turbidity [27]. The percentage cyanogenic glycoside content was determined using Equation 5.

Where

$$
\% \text { Cyanogenic glycoside }=T \times 108 \times \frac{N}{1000} \times \frac{V e}{V a} \times \frac{100}{W}
$$

$\mathrm{T}=$ Titre value.

$108=$ Equivalent weight of silver nitrate.

$\mathrm{N}=$ Normality of silver nitrate solution.

$\mathrm{V}_{\mathrm{e}}=$ Extract volume.

$\mathrm{V}_{\mathrm{a}}=$ Aliquot volume titrated.

$\mathrm{W}=$ Weight of sample in grams.

$1000=$ Scaling factor to obtain silver nitrate content of $1.0 \mathrm{ml}$ of silver nitrate solution.

\subsubsection{Determination of Oxalate Content}

Five grams $(5 \mathrm{~g})$ of the ground sample was placed in a $100 \mathrm{ml}$ flask and $20 \mathrm{ml}$ of $0.3 \mathrm{~N}$ hydrochloric acid solution was poured into the flask. It was stirred with a magnetic stirrer at $50^{\circ} \mathrm{C}$ for I hour. The mixture was filtered with filter paper (No. 42) and the extract stored and the process was repeated. Both extracts were combined and made up to a volume of $100 \mathrm{mlwith}$ distilled water. Twenty milliliters $(20 \mathrm{ml})$ of the filtrate was poured into a $100 \mathrm{ml}$ beaker and three drops of phenolphthalein indicator was added. Then, $5 \mathrm{~N}$ ammonium hydroxide solution was added in drops until the reaction mixture was alkaline (pinkish). Glacial ethanoic acid was added in drops until the pink coloration disappeared and a few more drops were added to make the mixture acidic. Next, $5 \mathrm{ml}$ of $5 \%$ calcium chloride solution was added to the solution and the mixture was allowed to stand for 3 hours. It was centrifuged at 300r.p.m for 15 minutes and then the residue washed 3 times with hot water using a centrifugation technique. The residue was dissolved in $3 \mathrm{ml}$ of $3 \mathrm{~N}$ tetraoxosulphate $(\mathrm{VI})$ acid solution. The resulting solution was titrated with freshly prepared $0.01 \mathrm{~N}$ potassium permanganate solution until permanent pink coloration that lasted for about 30 seconds was obtained [28]. A blank titration was also conducted. The percentage oxalate content was determined using Equation 6.

Where

$$
\% \text { Oxalate }=\frac{X}{1} \times \frac{1}{1000} \times \frac{100}{1} a \times \frac{100}{S} b
$$

$\mathrm{X}=$ Weight of oxalate obtained by multiplying molar mass and molarity of oxalate.

$1000=$ Reference volume for molar concentration.

$100_{\mathrm{a}}=$ Total volume of extract.

$100_{\mathrm{b}}=$ Scaling factor to convert to percentage.

$\mathrm{S}=$ Weight of sample taken for analysis.

\subsubsection{Proximate Composition of the Samples of Pods of Rain Tree \\ 2.2.3.1. Determination of Moisture Content}

The AOAC [29] method was used. Two gramme-portions of each of the freshly ground samples (1, 2 and 3) were weighed into previously weighed dry crucibles. The crucibles with samples were dried in an oven at $105^{\circ} \mathrm{C}$, cooled in desiccators for ten minutes, reweighed and returned into the oven until a constant weight was attained [26]. The moisture content was calculated with the following Equation 7:

$$
\% \text { Moisture content }=\frac{W_{1}-W_{2}}{W_{1}} \times \frac{100}{1}
$$

Where:

$\mathrm{W}_{1}=$ the weight of sample before drying.

$\mathrm{W}_{2}=$ the weight of sample after drying.

Sample $1=$ Whole pod, Sample $2=$ pod without seed (pulp), Sample $3=$ seed . 


\subsubsection{Determination of Ash Content}

The Ash content was determined following the AOAC [29] method. Two grammes of the samples were weighed in triplicate into previously weighed silica crucibles. The samples inside the crucibles were charred on a heater inside a fume cupboard to drive off most of the smoke. The crucibles with the contents were transferred into a muffle furnace and heated for about four hours at $550^{\circ} \mathrm{C}$. They were cooled in a desiccator and weighed. The heating was repeated until the samples turned greyish white and attained constant weight. The ash content was then calculated as shown in Equation 8:

$$
\% \text { Ash }=\frac{\text { weight of ash }}{\text { weight of sample taken }} \times \frac{100}{1}
$$

\subsubsection{Determination of Crude Lipid (Ether - Extract)}

The total lipid content of the samples was determined using the AOAC [29] Soxhlet fat extraction method. Five grammes $(5 \mathrm{~g})$ of the sample were weighed into a pre-weighed fat free extraction thimble which was plugged tightly with cotton wool. The thimble was placed in the Soxhlet extractor fitted up with reflux condenser, all connected to a boiling flask containing $200 \mathrm{ml}$ of petroleum ether (Boiling point $60^{\circ} \mathrm{C}$ ) on a heating mantle. As the flask and petroleum ether were heated, the solvent evaporated and condensed into the thimble extracting oil from the sample and refluxed into the boiling flask with the extracted oil. This was done for 4 hours. At the end of extraction, the solvent (petroleum ether) was evaporated by heating at $70^{\circ} \mathrm{C}$ on a hot plate leaving the lipid extract in the flask. The flask with its contents were placed in an oven and dried at $110^{\circ} \mathrm{C}$ for one hour, cooled in a desiccator and re-weighed [26]. The percentage lipid was calculated as shown in Equation 9:

$$
\% \text { Ether extract } \frac{\text { Weight of oil }}{\text { Weight of sample }} \times \frac{100}{1}
$$

\subsubsection{Determination of Crude Protein}

The crude protein contents of the samples were determined using the micro-Kjeldahl apparatus as described by AOAC [29]. Two grammes of each of the samples was placed in a Kjeldahl flask and 30ml concentrated sulphuric acid $\left(\mathrm{H}_{2} \mathrm{SO}_{4}\right)$ added followed by the addition of $10 \mathrm{~g}$ potassium sulphate and $1 \mathrm{~g}$ copper sulphate. The mixture was gently heated for few minutes until frothing ceased; the heat was increased and the sample allowed digesting for three hours. The digest was allowed to cool, diluted with distilled water (washing the digestion flask) up to $100 \mathrm{ml}$. Ten milliliters $(10 \mathrm{ml})$ of the dilute digest was pipetted into a distillation flask and $10 \mathrm{ml}$ of $40 \%(\mathrm{w} / \mathrm{v}$ ) sodium hydroxide added. The mixture was distilled and the liberated ammonia collected in $10 \mathrm{ml}$ of $2 \%$ boric acid containing indicator. This was titrated with $0.01 \mathrm{~N}$ hydrochloric acid to grey coloured end point. A blank was also prepared without a sample and treated as above [26]. The amount of crude protein was then calculated by multiplying percentage nitrogen in the digest by the conversion factor (6.25) as shown in Equation 10.

Where

$$
\% N=\frac{(a-b) \times 0.01 \times 14 \times v}{W \times C} \times \frac{100}{1}
$$

$\mathrm{a}=$ the titre value of the digested sample.

$b=$ titre value of the blank sample.

$\mathrm{V}=$ volume after dilution.

$\mathrm{W}=$ weight of dried sample $(\mathrm{mg})$.

$\mathrm{C}=$ Aliquot of sample used.

$14=$ Atomic weight of Nitrogen.

Crude protein $=6.25 \times \mathrm{x}$.

\subsubsection{Determination of Crude Fibre}

AOAC [29] method was employed. Two grams of the ground samples were weighed in duplicate into a $600 \mathrm{ml}$, long Pyrex beaker and $200 \mathrm{ml}$ of $1.25 \% \mathrm{H}_{2} \mathrm{SO}_{4}$ solution was added. The beaker was covered with a watch glass and the content gently boiled on a hot plate for 30 minutes. The acid was removed by filtering through a muslin cloth over a Buckner funnel and the sample washed three times with $50 \mathrm{ml}$ of boiling water to free it of acid, before putting it back to the beaker. Then, $200 \mathrm{ml}$ of $1.25 \% \mathrm{NaOH}$ solution was added to the residue in the beaker, which was covered with a watch glass and gently boiled on a hot plate for 30 minutes and then filtered. The residue was washed into a weighed No. 2 sintered glass crucible with $50 \mathrm{ml}$ of boiling water and later washed twice with $30 \mathrm{ml}$ portions of petroleum spirit. The crucible was dried in the oven at $80^{\circ} \mathrm{C}$ to a constant weight and then ignited in a muffle furnace at $600^{\circ} \mathrm{C}$ until a light gray coloured ash was obtained. The crucible and content were cooled to ambient temperature in a desiccator and then weighed [26]. The crude fibre content was calculated as shown in Equation 11:

$$
\% \text { crude fibre }=\frac{\text { loss } \text { in weight on ignition }}{\text { weight of sample }} \times \frac{100}{1}
$$

\subsubsection{Determination of Carbohydrate Content}

The carbohydrate content was obtained by difference [26] as shown in Equation 12.

$\%$ Carbohydrate $=(100 \%-\%$ Moisture, $\%$ Crude protein $-\%$ Fat-\%Ash-\%Crude fibre $)$

\subsubsection{Statistical Analysis}

Triplicate data obtained were subjected to statistical analysis using SPSS software of version 21. Mean values were determined and One-Way ANOVA was done as well as Fisher's Least Significant Difference [30] was used to determine for the separation of the means at $(\mathrm{p} \leq 0.05)$. 


\section{Results and Discussion}

\subsection{Anti-Nutritional Composition (Mg/100g) of Rain Tree (Samanea saman) Pod Samples}

Oxalate, hydrogen cyanide, tannins, saponins, flavonoids and alkaloids were identified in all samples of Samanea saman pod Table 1 .

Oxalic acid as an anti-nutrient interfere with mineral availability particularly calcium. It binds with calcium and forms insoluble calcium oxalate which cannot be absorbed in the body. This may lead to death due to hypercalcimia in the renal tubules Murray, et al. [31]; Ifemeje [32]. Ladeji, et al. [33] reported that oxalates cause irritation and swelling in the month and throat. The oxalate of the pulp sample was $1.89 \mathrm{mg} / 100 \mathrm{~g}$ which is significantly $(\mathrm{p}<0.05)$ higher than the oxalate $(1.49 \mathrm{mg} / 100 \mathrm{~g})$ of whole pod and $1.39 \mathrm{mg} / 100 \mathrm{~g}$ oxalate of seed sample Table 1 . This quantity of oxalate is within safe limit because $2 \%$ or more soluble oxalate can lead to toxicosis. They are therefore considered harmless when present in small amounts as shown in Table 1. The amount of oxalate in Samanea saman whole pod, pulp and seed samples is thus not harmful, more so, when cooking has been reported [34] to affect a significant reduction in total oxalate contents of plants. An unacceptably high value of $27.34 \mathrm{mg} / 100 \mathrm{~g}$ oil was reported for tropical almond [35].

Cyanogenic glycosides are hydrolysed by $\beta$-glucosidase producing sugars and a cyanohydrin which spontaneously decompose to cyanohydric acid ( $\mathrm{HCN})$ and a ketone or aldehyde [36]. HCN is extremely toxic to a wide spectrum of organisms due to its ability of linking with metals $\left(\mathrm{Fe}^{2+}, \mathrm{Mn}^{2+}\right.$ and $\left.\mathrm{Cu}^{2+}\right)$ that are functional groups of many enzymes, inhibiting processes like reduction of oxygen in the cytochrome respiratory chain, electron transport in the photosynthesis, and the activity of enzyme like catalase, oxidase [32]. Hydrogen cyanide is toxic when ingested by monogastric animals in large quantity [37]. The whole pod had HCN of $1.97 \mathrm{mg} / 100 \mathrm{~g}$ which is significantly $(\mathrm{p}<0.05)$ higher than the $\mathrm{HCN}(1.51 \mathrm{mg} / 100 \mathrm{~g})$ of pulp and $1.61 \mathrm{mg} / 100 \mathrm{~g}$ of seed samples Table 1. The hydrogen cyanide contents of these samples were low when compared to the report $(4.31-4.77 \mathrm{mg} / \mathrm{kg}$ ) of Ogueke, et al. [38] and maximum limit $(10 \mathrm{mg} / \mathrm{kg})$ recommended for garri [39]. Reduction in HCN might be due to the processing methods employed [40]. High level of hydrogen cyanide has been implicated for cerebral damage and lethargy in man and animals [34, 41].

Tannins are plant polyphenols, which have ability to form complexes with metal ions and with macromolecules such as proteins and polysaccharides [42]. Dietary tannins are said to reduce feed efficiency and weight gain in chicks [37]. Tannins are polyphenols and have been reported to exhibit anti-microbial actions. The presence of high level of tannins could confer on the users chemoprotective benefits [43]. The pulp had tannins of $0.86 \mathrm{mg} / 100 \mathrm{~g}$ which is significantly $(\mathrm{p}<0.05)$ higher than the tannins $(0.71 \mathrm{mg} / 100 \mathrm{~g})$ of whole pod and $0.56 \mathrm{mg} / 100 \mathrm{~g}$ of seed samples Table 1 . Tannins may form a less digestible complex with dietary proteins.

Table-1. Mean Values (mg/100g) of Anti-Nutrient Composition of Rain Tree (Samanea saman) Pod samples

\begin{tabular}{c|c|c|c|c}
\hline & \multicolumn{5}{c}{ SAMPLES (mg/100g) } \\
\hline Anti-Nutrients & Whole pod & Pulp & Seed & LSD \\
\hline Oxalate & $1.49 \pm 0.01^{\mathrm{b}}$ & $1.89 \pm 0.01^{\mathrm{a}}$ & $1.39 \pm 0.01^{\mathrm{c}}$ & 0.02 \\
\hline Hydrogen Cyanide & $1.97 \pm 0.01^{\mathrm{a}}$ & $1.51 \pm 0.01^{\mathrm{c}}$ & $1.61 \pm 0.01^{\mathrm{b}}$ & 0.02 \\
\hline Tannins & $0.71 \pm 0.01^{\mathrm{b}}$ & $0.86 \pm 0.01^{\mathrm{a}}$ & $0.56 \pm 0.01^{\mathrm{c}}$ & 0.02 \\
\hline Saponins & $27.07 \pm 0.01^{\mathrm{b}}$ & $28.46 \pm 0.01^{\mathrm{a}}$ & $26.51 \pm 0.01^{\mathrm{c}}$ & 0.02 \\
\hline Flavonoids & $0.51 \pm 0.01^{\mathrm{b}}$ & $1.00 \pm 0.01^{\mathrm{a}}$ & $0.49 \pm 0.01^{\mathrm{c}}$ & 0.02 \\
\hline Alkaloids & $1.71 \pm 0.01^{\mathrm{c}}$ & $1.41 \pm 0.01^{\mathrm{a}}$ & $1.86 \pm 0.01^{\mathrm{b}}$ & 0.02 \\
\hline
\end{tabular}

These tannins-protein complexes are astringent and adversely affect feed intake. The pod contains $0.86 \mathrm{mg} / 100 \mathrm{~g}$ of tannin due to this result taking the pod may not lower the availability of protein in the body or clotting with red blood cell as cause by excess tannin in human body. This suggests that this pod may be safe for consumption [44].

Saponins are glycosides, which include steroid saponins and triterpenoid saponins [42]. High levels of saponins in feed affect feed intake and growth rate in poultry. Reduction in feed intake has been ascribed to the bitter taste of saponins [37] and due to the irritating taste. Excess saponins causes hypocholestrolaemia because it binds cholesterol making it unavailable for absorption [45]. Saponin-protein complex formation can reduce protein digestibility [37]. Saponins were predominant in all the Samanea pod samples. The highest level of saponin was found in Samanea saman pulp $(28.46 \mathrm{mg} / 100 \mathrm{~g})$, followed by the whole pod $(27.07 \mathrm{mg} / 100 \mathrm{~g})$ and the seed $(26.51 \mathrm{mg} / 1 \mathrm{OOg})$. High levels of saponins have haemolytic effect on red blood cells and also reduce growth rate in animals. Saponins also possess some beneficial properties such as cholesterol lowering, anti-tumor and as antioxidant [33]. The concentration of the value of saponins from the analysis was $28.46 \mathrm{mg} / 100 \mathrm{~g}$ which is within the WHO permissible limit of $(48.50 \mathrm{mg} / 100 \mathrm{~g})$ as recommended in this study. Saponins possess a carbohydrate moiety attached to a triterpenoid or a steroidal aglycone [46]. Saponins reduce the uptake of glucose and cholesterol at the gut through intra-lumenal physico-chemical interactions. This could confer a chemo-protection against heart diseases to users [32].

Flavonoids, a group of natural substances with variable phenolic structures, are found in fruits, vegetables, grains, bark, roots, stems, flowers, tea and wine. The flavonoids are categorized in different classes as alkaloids, terpenoids and phenolics. Flavonoids carry out a number of protective functions in the human body. Many flavonoids have evolved as bioactive compounds that interfere with nucleic acid or proteins and show antimicrobial or insecticidal and pharmacological properties [47].The highest level of flavonoids was found in Samanea saman pulp $(1.00 \mathrm{mg} / 100 \mathrm{~g})$, followed by the whole pod $(0.51 \mathrm{mg} / 100 \mathrm{~g})$ and the seed $(0.49 \mathrm{mg} / 100 \mathrm{~g})$ as shown in Table 1 . Flavonoids possess anti-inflammatory, anti-oxidant, anti-allergic, hepato-protective, anti-thrombic, anti-viral and anti-carcinogenic activities. These properties may explain the use of Samanea saman for prevention and treatment of diseases [47].

Alkaloids are beneficial chemicals to plants with predator and parasite repelling effects. However, they inhibit certain mammalian enzymic activities such as those of phosphor-diesterase, prolonging the action of cyclic AMP. They also affect glucagons and thyroid stimulating hormones, while some forms have been reported to be 
carcinogenic [48]. Alkaloids were relatively lower in the Samanea saman pulp (1.41mg/100g) than the seed $(1.86 \mathrm{mg} / 100 \mathrm{~g})$ and whole pod $(1.71 \mathrm{mg} / 100 \mathrm{~g})$ as shown in Table 1 . It is noteworthy that at the concentration of alkaloids in edible plants, they are usually non-toxic because steaming or boiling reduces their levels in plant extracts [32].

\subsection{Proximate Composition of Rain Tree (Samanea saman) Pod Samples}

The fresh mature and ripe (brown) rain tree whole pod had a moisture content of $15.50 \%$ and understandably its pulp and seed had moisture contents of $19.30 \%$ and $9.20 \%$ respectively Table 2 . The values were significantly $(\mathrm{p} \leq 0.05)$ different from each other. Esuoso [8] found that Samanea saman husks, whole pods and seeds had moisture contents of $4.11 \%, 58.42 \%$ and $6.19 \%$ respectively. The slight variation in moisture content could be attributed to the drying conditions which the samples were subjected to before the analysis. Factors such as environmental conditions could also affect the moisture content of food materials. Barcelo and Barcelo [6] showed that the Samanea saman pod had a moisture content of $15.18 \%$. The moisture content of $15.50 \%$ for the whole pod obtained in this study is in line with the values $15.30 \%$ and $15.80 \%$ reported by Barcelo and Barcelo [6]. The moisture content of foods determines the water activity which influences the rates of chemical, microbial and enzymatic reactions in foods. By lowering the water activity through drying, microbial deterioration of foods can be delayed, reduced or eliminated.

The whole pod had higher ash content $(4.70 \%)$ than the pulp $(2.90 \%)$ or the seed $(2.60 \%)$, indicating that it has a higher concentration of minerals than pulp and seed. This is in line with Esuoso [8] who reported ash contents of $4.16 \%$ and $2.10 \%$ for Samanea saman whole pod and seed respectively. Barcelo and Barcelo [6] reported a relatively higher ash content of $5.12 \%$ for Samanea saman whole pod. Though, there were slight variations in the ash contents of the samples, the values fall within a close range of $2.4 \%$ to $5.12 \%$. Ash in food constitutes the residue remaining after all the moisture has been removed as well as the organic materials burnt away by igniting at temperature of about $500^{\circ} \mathrm{C}[49]$. Thus, ash content represents the total mineral content in foods.

Table-2. Mean values of the proximate composition of rain tree (samanea saman) pod samples.

\begin{tabular}{|c|c|c|c|c|c|}
\hline \multirow[b]{2}{*}{ No. } & \multirow[b]{2}{*}{$\begin{array}{c}\text { Proximate } \\
\text { Composition (\%) }\end{array}$} & \multicolumn{4}{|c|}{ Samples } \\
\hline & & Whole pod & Pulp & Seed & LSD \\
\hline 1 & Moisture & $15.50 \pm 0.01^{b}$ & $19.30 \pm 0.01^{\mathrm{a}}$ & $9.20 \pm 0.1^{\mathrm{c}}$ & 0.02 \\
\hline 2 & Ash & $4.70 \pm 0.01^{\mathrm{a}}$ & $2.90 \pm 0.01^{\mathrm{b}}$ & $2.6 \pm 0.01^{\mathrm{c}}$ & 0.02 \\
\hline 3 & Ether Extract & $3.31 \pm 0.01^{\mathrm{a}}$ & $2.52 \pm 0.01^{\mathrm{c}}$ & $2.66 \pm 0.01^{\mathrm{b}}$ & 0.02 \\
\hline 4 & Crude Protein & $13.21 \pm 0.01^{b}$ & $10.98 \pm 0.01^{\mathrm{c}}$ & $21.55 \pm 0.01$ & 0.02 \\
\hline 5 & Crude Fibre & $15.95 \pm 0.01^{\mathrm{a}}$ & $6.77 \pm 0.11^{\mathrm{c}}$ & $8.47 \pm 0.01^{\mathrm{b}}$ & 0.13 \\
\hline 6 & Carbohydrate & $47.33 \pm 0.01^{\mathrm{c}}$ & $57.53 \pm 0.01^{\mathrm{a}}$ & $55.52 \pm 0.01^{\mathrm{b}}$ & 0.02 \\
\hline
\end{tabular}

The lipid content (Ether extract) results in Table 2 shows that Samanea saman pod had the highest lipid content $(3.31 \%)$ among the samples with Samanea saman seed having $2.66 \%$ and the Samanea saman pulp having the lowest lipid content $(2.52 \%)$. The lipid content of all the samples were significantly $(\mathrm{p}<0.05)$ different from each other. Similarly, Esuoso [8] reported a lower lipid value of $0.82 \%$ for the whole pod and $1.20 \%$ lipid content for the seed. The variations observed in the lipid contents could be as a result of agronomical factors and analytical techniques. With ether extract (fat) values of the samples ranging from $2.52 \%$ (in pulp) to $3.31 \%$ (in whole pod), certainly the pod is not a good oil source, thus its seed could not be classified as an oil seed.

Among the three areas of Samanea saman pod studied, the seed had the highest protein value (21.55\%). The whole pod had protein value of $13.21 \%$ while its pulp had a value of $10.98 \%$. The differences between these values were significant $(\mathrm{p}<0.05)$. The protein value of $13.21 \%$ obtained in this study for the whole pod fell within the range of $10-18 \%$ reported by Dihigo, et al. [50] and Staples and Elevitch [2]. Semae, et al. [51] reported that the pods of rain tree to be highly digestible, having protein $(15.31-18.00 \%)$ content, is low in cost and is non-toxic [52, 53]. Esuoso [8] reported a whole pod protein value of $28.48 \%$ and that was the highest value observed in accessible literature for the pod. There was no specific report on the pulp with regards to proximate composition, but reports on the protein content of seed had values ranging from 22-31.60\% [8, 50]. Notwithstanding, the variations observed in the various reports, Samanea saman pods and seeds exhibited high protein contents which could be explored in animal feed as nutrient source to improve animal diet and possibly for humans.

The Samanea saman whole pod had a mean crude fibre content of $15.95 \%$ as compared to values of $8.47 \%$ and $6.77 \%$ for the seed and pulp respectively. The crude fibre content of the three samples were significantly $(\mathrm{p}<0.05)$ different. The crude fibre value of $15.95 \%$ obtained in this study for the whole pod is comparably much lower than a value of $33.4 \%$ reported by Esuoso [8] for the same material. Also, a crude fibre value of $8.47 \%$ seed obtained in this study is comparably lower than the value $16.15 \%$ reported by Esuoso [8] respectively for the same material. Though agronomical factors may have contributed to the variations in the results obtained, different analytical conditions may have also led to the variation. Crude fibres play important roles in digestion processes and the lowering of gastric cholesterol [21].

Table 2 showed that Samanea saman pulp had the highest carbohydrate content $(57.53 \%)$ as compared to the seed with a value of $55.52 \%$ and the whole pod with the least carbohydrate content of $47.33 \%$. There were significant $(\mathrm{p}<0.05)$ differences among the carbohydrate contents of the three samples. Since the carbohydrate content was obtained by difference, the lower carbohydrate content observed in the whole pod could be a reflection of the higher crude fibre content of the whole pod which was much higher than that of the Samanea saman pulp and seed. The result obtained in this research showed some similarities with those previously reported by other researchers, where the seed had higher carbohydrate than the pod. Esuoso [8] also reported lower carbohydrate values of $26.73 \%$ and $34.89 \%$ for the Samanea pod and seed, respectively. The relatively high carbohydrate content obtained in this research suggests that the various parts of Samanea saman pods could serve as energy source when included in animal feed. 


\section{Conclusion and Recommendation}

\subsection{Conclusion}

The levels of hydrogen cyanide, oxalate, tannins and flavonoid were relatively low in all the samples of Samanea saman pods. The results show that all the anti-nutrients were significantly $(\mathrm{p}<0.05)$ different in all the samples. The relative low levels of these anti-nutrients confirm the safety of the fruit for industrial utilization, human and animal consumption. It was observed that saponins were the predominant anti-nutrient identified in all the pod samples ranging from $26.51 \mathrm{mg} / 100 \mathrm{~g}$ (seed) to $28.46 \mathrm{mg} / 100 \mathrm{~g}$ (pulp) while the rest were less than 2.0mg/10og. The result of the anti-nutritional composition of Samanea saman pods is evidence that utilization of Samanea saman might not have any negative impact in the body. Though saponin was the most abundant antinutrient in all the Samanea saman pod samples, the highest level $(26.51 \mathrm{mg} / 100 \mathrm{~g})$ identified in the pulp is still within the safe level of less than $146 \mathrm{mg} / 100 \mathrm{~g}$.

The result of proximate composition of pod of rain tree showed that pulp had higher moisture content and carbohydrate content than whole pod and seed samples. It was observed that the whole pod had higher ash, ether extract and crude fibre than the pulp and seed samples whereas the seed was richer in protein content than the whole pod and pulp samples. The relative high protein (10.98\% to $21.55 \%)$ and carbohydrate (47.33\% to $57.53 \%)$ contents of the rain tree (Samanea saman) pod samples suggest that they can be used as nutrient supplement in animal feeds and the seeds can be utilized as a rich protein meal in human diets.

\subsection{Contributions to Knowledge}

Within the limits of this research work, the study has, no doubt, contributed immensely to knowledge, which is as follows:

- This study has provided information for the utilization of the rain tree (Samanea saman) pod in food production.

- This study has also opened another area of research such as pod utilization in food flavor and animal feed development.

- The study has revealed the nutrient (protein, carbohydrate, lipid, ash, fiber and moisture) potential of these pods which are presently littering as waste.

- This study has also opened another area of research such as pod utilization in food formulation and animal feed development.

\subsection{Recommendations}

This study leads to the need of further detailed search on the immense potentials of rain tree. The results of the present study are promising thus indicating the utilization of the pods of $S$. saman as a significant source of bioactive that if harnessed in the formulation of nutraceutical beverage could offer a whole lot of health benefit to the users. Investors should be encouraged to invest in machines that can facilitate the removal of seeds from the pods.

\section{References}

[1] U. Mbanali, M. Chukwu, and M. Iwuagwu, "Variation in the functional properties of blends of heat-treated local thickening seeds and cocoyam flour," Research Journal of Food Science and Nutrition, vol. 3, pp. 74-83, 2018.Available at: https://doi.org/10.31248/rjfsn2018.053.

[2] G. W. Staples and C. R. Elevitch, Samanea saman (rain tree). Species profiles for pacific Island, Afroforestry. Holualoa, Hawaii: Permanet Agriculture Resources (PAR), 2006.
E. M. Flores, Samanea saman (jacq) Merr. In: J.A. Vozzo (Ed.), Tropical Tree Seed Manual. Agriculture Handbook 721. Washington DC: USDA Forest Service, 2002.

[4] M. Hagan, D. Armstrong, and A. Dadson, "Growth performance and economic evaluation of broiler chicken fed with rain tree (Samanea saman) seed meal," Cogent Food E Agriculture, vol. 2, pp. 1-10, 2016.Available at: https://doi.org/10.1080/23311932.2016.1277445.

[5] S. Rath, K. Nayak, C. Pradhan, T. Mohanty, S. Sarkar, K. Mohanta, B. Paul, and S. Giri, "Evaluation of processed rain tree (Samanea saman) pod meal as a non-conventional ingredient in the diet of Catla catla Fry," Animal Nutrition and Feed Technology, vol. 17, pp. 323-332, 2017.Available at: https://doi.org/10.5958/0974-181x.2017.00031.2.

[6] P. Barcelo and J. Barcelo, "The potential of Samanea saman (Jack) Merr pods as feed for goat," International Journal of Zoology Research, vol. 2, pp. 40-43, 2012.

[7] R. S. Samuel, "Yield potential of rain tree (Samanea saman Merr.) as feedstock for biofuel production," Isu-Cabagan Journal of Research, vol. 20, pp. 20-22, 2010.

K. O. Esuoso, "The nutritive value of monkey pod," Journal of Asiatic Society of Begal, vol. 66, pp. 23-27, 1996.

D. 1. R. Cruz, "Potential of acacia pods as feeds for chickens," BAR, Research and Development Digest, vol. 5, pp. 1-19, 2003.
$[10] \quad$ J. C. Okonkwo, "Utilization of raw autoclaved whole pods of Samanea saman by the domestic rabbits. Retrieved from www.researchgate.net," 2010.

[11] L. Obasi Nnamdi, A. Egbuonu, P. Ukoha, and P. Ejikeme, "Comparative phytochemical and antimicrobial screening of some solvent extracts of Samanea saman (fabaceae or mimosaceae) pods," African Journal of Pure and Applied Chemistry, vol. 4, pp. 206-12, 2010.

[12] P. O. Ukoha, E. A. Cemaluk, O. L. Nnamdi, and E. P. Madus, "Tannins and other phytochemical of the Samanaea saman pods and their antimicrobial activities," African Journal of Pure and Applied Chemistry, vol. 5, pp. 237-244, 2011.

[13] M. N. Chukwu, N. O. Kabuo, E. U. Onyeka, T. C. Odom, O. Nwogu, N. J. Nwokocha, and J. C. Ndulaka, "Production and organoleptic attributes of ogiri-ahuekere produced from groundnut (Arachis hypogaea Linn) seeds," Research Journal of Food Food Science and Quality Control, vol. 3, pp. 63-72, 2017.

[14] H. Inuwa, V. Aina, B. Gabi, I. Aimola, and A. Toyin, "Comparative determination of antinutritional factors in groundnut oil and palm oil," Advance Journal of Food Science and Technology, vol. 3, pp. 275-279, 2011.

[15] M. N. Chukwu, C. S. Nwakodo, Q. Alozie, and J. C. Ndulaka, "Comparative studies on organoleptic properties of ogiri-ahuekere and ogiri-egusi condiments," Research Journal of Food Science and Quality Control, vol. 4, pp. 11-19, 2018 a.

[16] V. N. Enujiugha and O. Ayodele-Oni, "Evaluation of nutrients and some anti-nutrients in lesser-known underutilized seeds," International Journal of Food Science E Technology, vol. 38, pp. 525-528, 2008.

[17] M. N. Chukwu, C. S. Nwakodo, J. C. Ndulaka, and N. J. Nwokocha, "Production and proximate composition of ogiri-ahuekere (Arachis hypogaea Linn) seed condiment," Research Journal of Agricultural and Environmental Management, vol. 7, pp. 007-017, 2018 b. 
[18] O. Adebowale and K. Maliki, "Effect of fermentation period on the chemical composition and functional properties of Pigeon pea (Cajanus cajan) seed flour," International Food Research Journal, vol. 18, pp. 1329-1333., 2011.

[19] B. F. Olanipekun, E. T. Otunola, and O. J. Oyelade, "Effect of fermentation on anti-nutritional factors and in vitro protein digestibility of Bambara Nut (Voandzeia subterranean L.)," Food Science and Quality Management, vol. 39, pp. 98-1 $10,2015$.

[20] J. C. Okaka, Handling, storage and processing of plant foods. Enugu, Nigeria: OCJ Academic Publishers, 2009.

[21] D. Okwu, "Phytochemicals, vitamins and mineral contents of two Nigerian medicinal plants," International Journal of Molecular Medicine and Advance Science, vol. 1, pp. 375-381, 2005.

[22] AOAC, Association of official analytical chemists, 18th ed. Arlington, Virginia, USA: Official Methods of Analysis of AOAC International, 2006.

[23] M. O. Bello, O. S. Falade, S. R. A. Adewusi, and N. O. Olawore, "Studies on the chemical composition and antinutrients of some lesser known Nigeria fruits," African Journal of Biotechnology, vol. 7, pp. 3972-3979, 2008.

[24] P. P. Fu, Q. Xia, G. Lin, and M. W. Chou, "Genotoxic pyrrolizidine alkaloids-mechanisms leading to DNA adduct formation and tumorigenicity," International Journal of Molecular Sciences, vol. 3, pp. 948-964, 2002.Available at: https://doi.org/10.3390/i3090948.

G. I. Onwuka, Food analysis and instrumentation: Theory and practice. Lagos, Nigeria: Naphthali Print, 2005.

G. I. Onwuka, Food analysis and instrumentation: Theory and practice, 2nd ed. Lagos: Naphtali Prints, 2018.

A. U. Osagie, Anti-nutritional factors. In: Nutritional Quality of plant foods. (Ed.) vol. 21. Benin City Nig: Ambolk Press, 1998.

S. Adeniyi, C. Orjiekwe, and J. Ehiagbonare, "Determination of alkaloids and oxalates in some selected food samples in Nigeria," African Journal of Biotechnology, vol. 8, pp. 66-73, 2009.

[29] AOAC, Association of official analytical chemists, 15th ed. Gaithersburg, MD, USA: Official Methods of Analysis of AOAC International, 2000.

[30] J. Pallant, SPSS survival manual. Berkshire: Open University Press, 2004.

[31] R. K. Murray, O. K. Granner, P. A. Mayers, and V. W. Rodwell, Harpers biochemistry, 26th ed. London: McGraw-Hill, 2003.

[32] J. Ifemeje, "Chemical and phytochemical compositions of Mucuna pruriens leaves," African Journal of Science and Research, vol. 5, pp. $14-17,2016$.

[33] O. Ladeji, C. Akin, and H. Umaru, "Level of antinutritional factors in vegetables commonly eaten in Nigeria," African Journal of Nature and Science, vol. 7, pp. 71-73, 2004.

[34] A. Ekop, "Determination of chemical composition of gnetum Africanum (AFANG) seeds," Pakistan Journal of Nutrition, vol. 6, pp. 40-43, 2007.Available at: https://doi.org/10.3923/pjn.2007.40.43.

[35] L. Nwaogu, C. Alisi, and O. Ojiako, "Studies on the nutritional and phytochemical properties of Persea Americana seed," BioResearch, vol. 6, pp. 320-322, 2008.Available at: https://doi.org/10.4314/br.v6i1.28658.

[36] A. F. Liza and H. P. P. Maria, "Cyanogenic glycosides in plants," Brazilian Archives of Biology and Technology, vol. 43, pp. 487-492, 2000.

[37] A. O. Ogbe and J. P. Affiku, "Proximate study, mineral and anti-nutrient composition of Moringa oleifera leaves harvested from Lafia, Nigeria: Potential benefits in poultry nutrition and health," Journal of Microbiology, Biotechnology and Food Sciences, vol. 1, pp. 296-308, 2012.

[38] C. C. Ogueke, C. Ehirim, C. I. Owuamanam, I. Ahaotu, and I. A. Olawuni, "Quality characteristics and HCN in gari as affected by fermentation variables," International Journal of Life Sciences, vol. 2, pp. 21-28, 2013.

[39] Codex, "Cereals, pulses, legumes and vegetable proteins: Codex standard for gari. Codex Standard 151-1989, FAO/WHO Codex Alimentarius Commission Rome," pp. 20-23, 2007.

[40] O. A. Abiodun, A. Adepeju, J. Odedeji, and A. Amanyunose, "Chemical, anti-nutritional and sensory attributes of melon enriched gari," Applied Tropical Agriculture, vol. 21, pp. 14-19, 2016.

[41] P. Agbaire and O. Emoyan, "Nutritional and antinutritional levels of some local vegetables from Delta State, Nigeria," African Journal of Food Science, vol. 6, pp. 8-11, 2012.Available at: https://doi.org/10.5897/ajfs 111.175 .

[42] H. Dei, S. Rose, and A. Mackenzie, "Shea nut (Vitellaria paradoxa) meal as a feed ingredient for poultry," World's Poultry Science Journal, vol. 63, pp. 611-624, 2007.Available at: https://doi.org/10.1017/s0043933907001651.

[43] O. Enechi and I. Odonwodo, "An assessment of the phytochemical and nutrient composition of the pulverized root of Cissus quadrangularis," Bio-Research, vol. 1, pp. 63-68, 2003.Available at: https://doi.org/10.43 14/br.v 1i1.28519.

[44] E. Shaba, M. Ndamitso, J. Mathew, M. Etsunyakpa, A. Tsado, and S. Muhammad, "Nutritional and anti-nutritional composition of date palm (Phoenix dactylifera L.) fruits sold in major markets of Minna Niger State, Nigeria," African Journal of Pure and Applied Chemistry, vol. 9, pp. 167-174, 2015.Available at: https://doi.org/10.5897/ajpac2015.0643.

[45] K. Soetan and O. Oyewole, "The need for adequate processing to reduce the antinutritional factors in plants used as human foods and animal feeds: A review," African Journal of Food Science, vol. 3, pp. 223-232, 2009.

[46] K. Sridhar and R. Bhat, "Lotus-A potential nutraceutical source," Journal of Agricultural Technology, vol. 3, pp. $143-155,2007$.

[47] A. N. Panche, A. D. Diwan, and S. R. Chandra, "Flavonoids: An overview," Journal of Nutritional Science, vol. 5, pp. 1-15, 2016.

[48] J. Okaka, C, N. J. Enoch, and N. C. Okaka, "Physicochemical and functional properties of cowpea powders processed to reduce bean flavor," Journal of Food Science, vol. 44, pp. 1235-1240, 1992.

[49] K. K. Raja, K. D. Srinivas, and R. E. Raghava, "Chemical composition and in vitro evaluation of rain tree (Albizia saman) pods as a livestock feed," International Journal of Science, Environment and Technology, vol. 6, pp. 3105 - 3109, 2017.

[50] L. Dihigo, L. Savón, and Y. Rosabal, "Determination of the in vitro digestibility of dry matter and neutral detergent fiber in five forage plants using the rabbit cecal inoculum," Cuban Journal of Agricultural Science, vol. 38, pp. 287-290, 2004.

[51] S. Semae, P. Kongmun, C. Vajrabukka, S. Chanpongsang, and S. Prasanphanich, "Effects of different levels of rain tree (Samanea saman) pods in meal concentrate on in vitro fermentation by a gas production technique," Kasetsart Journal, Natural Science, vol. 47, pp. 704-711, 2013.

[52] S. Hosamani, N. Gowda, and S. Kololgi, "Evaluation of chemical, nutritive and feeding value of rain tree pods," Karnataka Journal of Agricultural Sciences, vol. 18, pp. 110-113, 2005.

[53] T. Jetana, C. Vongpipatana, S. Thongruay, S. Usawang, and S. Sophon, "Apparent digestibility, nitrogen balance, ruminal microbial nitrogen production and blood metabolites in Thai Brahman cattle fed a basal diet of rice straw and supplemented with some tropical protein-rich trees," Asian-Australasian Journal of Animal Sciences, vol. 23, pp. 465-474, 2010.Available at: https://doi.org/10.5713/ajas.2010.90316. 